\title{
PEMANFAATAN TANAMAN KAKTUS BERDURI DALAM MENURUNKAN KEKERUHAN PADA AIR SUNGAI \\ Erlani ${ }^{1}$ dan Nia Triani \\ 1,2Jurusan Kesehatan Lingkungan Poltekkes Kemenkes Makassar \\ niatriani260@gmail.com
}

\begin{abstract}
Water is used by humans for various purposes such as drinking, washing, cooking and so forth. Then the use of water must fulfill the health requirements, is water must fulfill the requirements of Physical, Chemical, Bacteriological, and Radioactive. One of the problems that are often encountered are the turbidity that does not fulfill the standards according to Permenkes. 416 / MENKES / PER / IX / 1990 on the requirement of clean water quality. This study aims to determine the level of turbidity in water. The type of this study is an experiment that is to see the benefits of cactus plants in reducing turbidity in the water Je'neberang river in Kab. Gowa. The results of this study showed that the level of turbidity before treatment was 59.9 NTU, and after being treated by doing three experiments at each dose, and obtained the average percentage of the decrease at a dose of $15 \mathrm{ml}$ is $78.82 \%$, the dose $20 \mathrm{ml}$ is $82.8 \%$, and $25 \mathrm{ml}$ dose is $83.91 \%$. The conclusion of this research is the decrease of turbidity level after being treated by using cactus plant in the form of solution as coagulant by using coagulation method, it can be said its fulfill the requirement according to the standard by Permenkes. 416 / MENKES / PER / IX / 1990 on the condition of clean water quality in the case of turbidity of 25 NTU. For the next researcher should do toxicity test first on water that has been done with cactus processing plants. Keywords: Coagulant, Coagulation, Cactus Plant, Turbidity, River Water.
\end{abstract}

\section{ABSTRAK}

Air digunakan manusia untuk berbagai keperluan seperti minum, mencuci, memasak dan lain sebagainya. Maka penggunaan air harus memenuhi syarat kesehatan, yaitu air harus memenuhi syarat Fisik, Kimia, Bakteriologis, dan Radioaktif. Salah satu bentuk permasalahan yang sering di jumpai yaitu kekeruhan yang tidak memenuhi standar yang telah ditetapkan oleh Permenkes No. 416/MENKES/PER/IX/1990 tentang syarat kualitas air bersih. Penelitian ini bertujuan untuk mengetahui kadar kekeruhan pada air. Adapun jenis penelitian ini merupakan eksperimen yaitu untuk melihat manfaat tanaman kaktus dalam menurunkan kekeruhan pada air sungai Je'neberang yang berada di Kab. Gowa. Hasil penelitian ini menunjukkan bahwa kadar kekeruhan sebelum diberi perlakuan sebesar 59,9 NTU, dan setelah diberi perlakuan dengan melakukan 3 kali percobaan pada masing- masing dosis, dan didapatkan rata-rata hasil persentase penurunan pada dosis $15 \mathrm{ml}$ yakni $78,82 \%$, dosis $20 \mathrm{ml}$ yakni $82,8 \%$, dan dosis $25 \mathrm{ml}$ yakni $83,91 \%$. Kesimpulan dalam penelitian ini adalah penurunan kadar kekeruhan setelah diberi perlakuan dengan menggunakan tanaman kaktus dalam bentuk larutan sebagai koagulan dengan menggunakan metode koagulasi, dapat dikatakan memenuhi syarat sesuai dengan standar oleh Permenkes No. 416/MENKES/PER/IX/1990 tentang syarat kualitas air bersih dalam hal kekeruhan yakni 25 NTU. Untuk peneliti selanjutnya sebaiknya melakukan uji toksisitas terlebih dahulu pada air yang sudah di lakukan pengolahan dengan tanaman kaktus

Kata Kunci : Koagulan, Koagulasi, Tanaman Kaktus, Kekeruhan, Air Sungai

\section{PENDAHULUAN}

Air merupakan zat kimia yang penting bagi semua bentuk kehidupan di bumi. Air menutup hampir $71 \%$ permukaan bumi, dimana sekitar 1,4 triliun kilometer kubik air tersedia di bumi. Sebagian besar terdapat dilautan (air asin) dan pada lapisan-lapisan es (di kutub dan puncakpuncak gunung). Air juga diperoleh dari hujan, sungai, air permukaan (tawar), danau, uap air, dan lautan es.

Tubuh manusia mengandung 60-70 persen air dari seluruh berat badan. Air di daerah jaringan lemak terdapat kira-kira 90 persen. Darah dan getah bening sebahagian besar terdiri dari air. (Sanropie dkk, 1984).

Air adalah sumber kehidupan. Tidak hanya manusia bahkan semua makhluk hidup di bumi memiliki ketergantungan terhadap air. Air digunakan manusia untuk berbagai keperluan seperti minum, mencuci, memasak dan lain sebagainya. Sejak jaman dahulu, manusia selalu mencari tempat tinggal yang berdekatan dengan sumber air, dan hal ini berlaku hingga sekarang. Manusia bisa hidup sebulan tanpa makan, tetapi hanya bisa bertahan beberapa hari saja tanpa air. (Sujadi, 2008).

Air sungai merupakan salah satu sumber air baku yang dapat dijadikan sebagai sumber air namun kondisi dan karakteristik sungai yang mengalami perubahan kualitas menjadi salah satu pertimbangan khusus dan mutlak dilakukan pengolahan sebelum air sungai tersebut dimanfaatkan untuk pemenuhan kebutuhan seharihari masyarakat, untuk itu diperlukan adanya suatu pengolahan sumber air tersebut agar dapat dimanfaatkan masyarakat. (Kusumarta, 2015).

Khususnya di Kabupaten Gowa penyediaan air bersih di sediakan oleh PDAM Gowa dengan sumber air baku berasal dari DAM Bili-bili dan Sungai Je'neberang. Penyediaan air bersih oleh PDAM Gowa sering terkendala 
Jurnal Sulolipu : Media Komunikasi Sivitas Akademika dan Masyarakat

Vol. 17 No.II 2017

e-issn : 2622-6960, p-issn : 0854-624X

terutama dari segi kualitas yaitu masalah kekeruhan yang sering tidak menentu.

Kekeruhan sumber air baku PDAM Gowa

sering berubah- ubah tergantung tinggi rendahnya curah hujan dan adanya longsoran (run off) dari Gunung Bawakaraeng, hal ini disebabkan karena sedimen yang dihasilkan sangat tinggi, sehingga pengolahan air untuk mengatasi kekeruhan dalam hal ini penggunaan bahan koagulan sering berubah-ubah tergantung tinggi rendahnya tingkat kekeruhan yang biasanya hanya dengan menggunakan Aluminium Sulfat (tawas), tetapi jika tingkat kekeruhan cukup tinggi maka dipergunakan bahan koagulan lain misalnya Poly Aluminium Chloride, Ferri Chlorida atau Ferro Sulfat. (Waris, 2008).

Proses-proses utama di dalam pengolahan air atau air sungai untuk dijadikan air bersih dengan sistem saringan pasir cepat adalah proses koagulasi atau flokulasi (penggumpalan), sedimentasi (pengendapan), filtrasi (penyaringan), dan desinfeksi.

Koagulasi atau flokulasi adalah suatu proses pemisahan partikel-partikel halus penyebab kekeruhan dari dalam air. Proses pemisahan di lakukan dengan cara pembubuhan bahan koagulan ke dalam air yang mengakibatkan partikel-partikel halus menggumpal menjadi partikel-partikel yang lebih besar sehinnga mudah dipisahkan dari air dengan cara di endapkan. Bahan koagulan yang digunakan pada penelitian ini adalah tanaman kaktus hal ini dikarenakan penelitian yang dilakukan sebelumnya oleh Shilpa et al. (2012), menunjukkan bahwa kaktus Opuntia ficus-indica mengurangi kekeruhan air danau dari 83 NTU menjadi 9,1 NTU. Getah (mucilage) dari $O$. ficus-indica mengandung asam galakturonat, rhamnosa, ksilosa, arabinosa dan galaktosa. Pada penelitian menunjukkan bahwa asam galakturonat berperan sebagai zat koagulan dan mekanisme koagulasinya adalah adsorpsi dan penggabungan dimana partikel tidak bersentuhan satu sama lain tetapi terikat pada senyawa seperti polimer dari kaktus.

Penyimpangan terhadap standar kualitas dalam hal kekeruhan melebihi batas yang telah ditetapkan akan menggangu estetika dan mengurangi efektifitas desinfeksi air. (Sanropie dkk 1984). Maka dari itu peneliti tertarik melakukan penelitian mengenai pemanfaatan tanaman kaktus berduri dalam menurunkan kekeruhan pada air sungai.

Adapun tujuan dalam penelitian ini adalah:

1. Tujuan Umum
Untuk mengetahui manfaat tanaman kaktus berduri sebagai koagulan dalam menurunkan kekeruhan pada air sungai.

2. Tujuan Khusus

a. Untuk mengetahui tingkat kekeruhan pada air sungai sebelum di lakukan pengolahan.

b. Untuk mengetahui penurunan tingkat kekeruhan air sungai setelah di lakukan penambahan rebusan tanaman kaktus dengan dosis 15 $\mathrm{ml} / 500 \mathrm{ml}$ sampel air.

c. Untuk mengetahui penurunan tingkat kekeruhan air sungai setelah di lakukan penambahan rebusan tanaman kaktus dengan dosis 20 $\mathrm{ml} / 500 \mathrm{ml}$ sampel air.

d. Untuk mengetahui penurunan tingkat kekeruhan air sungai setelah di lakukan penambahan rebusan tanaman kaktus dengan dosis 25 $\mathrm{ml} / 500 \mathrm{ml}$ sampel air.

\section{BAHAN DAN METODE}

\section{Jenis Penelitian}

Jenis penelitian yang digunakan dalam penelitian ini adalah jenis penelitian eksperimen guna untuk mengetahui variasi dosis terhadap penurunan kekeruhan pada air sungai, dengan 3 kali percobaan.

2. Lokasi dan Waktu Penelitian

a. Lokasi Penelitian

Adapun lokasi untuk melakukan pemeriksaan tingkat Kekeruhan adalah di Laboratorium Jurusan Kesehatan Lingkungan Poltekkes Makassar.

b. Lokasi Pengambilan Sampel

Adapun lokasi pengambilan sampel air sungai yaitu bertempat di sungai jeneberang Kab. Gowa.

\section{Waktu penelitian}

a. Tahap Persiapan yang meliputi pengumpulan data sekunder yang berlangsung pada Bulan Januari - April 2017.

b. Tahap Pelaksanaan meliputi kegiatan penelitian yang berlangsung pada bulan Mei - Juni 2017.

\section{Variabel Penelitian}

a. Variabel Bebas adalah variabel yang berpengaruh terhadap varibel Bebas, dalam penelitian ini yaitu rebusan tanaman kaktus, koagulasi. 
b. Variabel Terikat adalah variabel yang di pengaruhi oleh variabel terikat, dalam hal ini adalah penurunan tingkat kekeruhan pada Air Sungai.

c. Variabel Pengganggu adalah yang mempengaruhi variabel bebas dan terikat, dalam hal ini $\mathrm{pH}$ dan suhu.

\section{Definisi Operasional dan Kriteria}

\section{Objektif}

a. Air Sungai dalam penelitian ini adalah air yang diambil di sungai Je'neberang Kab. Gowa.

b. Kekeruhan adalah tingkat padatan tersuspensi yang ada di sungai Je'neberang, dengan menggunakan skala NTU (Nefelometrik Turbidity Unit). Kriteria Objektif :

1) Memenuhi syarat apabila kadar kekeruhan pada air sungai tidak melebihi 25 NTU setelah di lakukan pengolahan sesuai dengan standar (Permenkes 416/menkes/per/ix/1990).

2) Tidak memenuhi syarat apabila kadar kekeruhan pada air sungai melebihi 25 NTU setelah di lakukan pengolahan sesuai dengan standar (Permenkes tentang standar kualitas air bersih nomor 416/menkes/per/ix/1990).

c. Tanaman Kaktus yang digunakan dalam penelitian ini adalah Jenis Opuntia ficus-indica.

d. Koagulasi dalam penelitian ini adalah proses penambahan rebusan tanaman kaktus dengan dosis 15, 20, dan $25 \mathrm{ml}$ dengan percobaan 3 kali, terhadap air keruh sehingga terjadi penggumpalan atau penggabungan partikel- partikel halus yang tidak dapat diendapkan secara gravitasi.

e. Suhu adalah besaran yang menyatakan derajat panas dingin air sungai Je'neberang dengan satuan $\left({ }^{\circ} \mathrm{C}\right)$.

f. $\mathrm{pH}$ adalah derajat keasaman yang digunakan untuk menyatakan tingkat keasaman dan kebasaan pada air sungai Je'neberang, diukur dengan menggunakan $\mathrm{pH}$ meter.

\section{Analisa Data}

Data dianalisa secara deskriptif yaitu dengan mengetahui besarnya penurunan tingkat kekeruhan setelah dilakukan perlakuan dengan menggunakan tanaman kaktus.

\section{HASIL PENELITIAN}

Dengan sampel air sungai Jeneberang dan melakukan pengolahan dengan menggunakan tanaman kaktus sebagai koagulan dalam menurunkan kekeruhan pada air sungai dengan menggunakan variasi dosis $15 \mathrm{ml}, 20 \mathrm{ml}$, dan 25 $\mathrm{ml}$ dengan 3 kali replikasi:

Tabel 1

Hasil Pemeriksaan Kekeruhan Sebelum dan Sesudah Perlakuan Dengan Dosis $15 \mathrm{ml}$

\begin{tabular}{lcccc}
\hline & & \multicolumn{2}{c}{$\begin{array}{c}\text { Kadar Kekeruhan } \\
\text { (NTU) }\end{array}$} & $\begin{array}{c}\text { Persentase } \\
\text { Penurunan }\end{array}$ \\
No. & Percobaan & Sebelum & Sesudah & $(\%)$ \\
\hline 1. & I & 59,9 & 15,28 & 74,50 \\
2. & II & 59,9 & 11,48 & 80,83 \\
3. & III & 59,9 & 11,29 & 81,15 \\
\multicolumn{2}{r}{ Rata- Rata } & $\mathbf{5 9 , 9}$ & $\mathbf{1 2 , 6 8}$ & $\mathbf{7 8 , 8 2}$ \\
\hline
\end{tabular}

Berdasarkan Tabel 1 diketahui bahwa kadar kekeruhan sebelum dilakukan pengolahan sebsar 59,9 NTU, dan kontrol sebesar 20,15 NTU, setelah diberi perlakuan dengan menggunakan rebusan tanaman kaktus $15 \mathrm{ml}$, pada percobaan pertama setelah diberi perlakuan di peroleh 15,28 NTU, dengan penurunan $74,50 \%$ Pada percobaan kedua diperoleh 11,48 NTU, dengan persentase penurunan $80,83 \%$. Sedangkan percobaan ketiga diperoleh 11,29 NTU, dengan persentase penurunan $81,15 \%$. Adapun rata-rata persentase penurunan $78,82 \%$.

\section{Tabel 2}

Hasil Pemeriksaan Kekeruhan Sebelum dan

Sesudah Perlakuan Dengan Dosis $20 \mathrm{ml}$

\begin{tabular}{lcccc} 
No. & Percobaan & $\begin{array}{c}\text { Kadar Kekeruhan } \\
\text { (NTU) }\end{array}$ & $\begin{array}{c}\text { Persentase } \\
\text { Penurunan }\end{array}$ \\
\hline & & Sebelum & Sesudah & $(\%)$ \\
1. & I & 59,9 & 11,29 & 81,15 \\
2. & II & 59,9 & 10,15 & 83,05 \\
3. & III & 59,9 & 9,46 & 84,20 \\
\multicolumn{2}{l}{ Rata- Rata } & 59,9 & 10,3 & 82,8 \\
\hline
\end{tabular}

Berdasarkan tabel 2 diketahui bahwa kadar kekeruhan sebelum pengolahan sebesar 59,9 NTU, dan kontrol sebesar 18,65 NTU. Setelah diberi perlakuan dengan menggunakan rebusan 
tanaman kaktus $20 \mathrm{ml}$, pada percobaan pertama diperoleh hasil 11,29 NTU, dengan persentase penurunan $81,15 \%$. Pada percobaan kedua diperoleh 10,15 NTU, dengan persentase penurunan $83,05 \%$. Sedangkan pada percobaan ketiga setelah diberi perlakuan hasil yang diperoleh 9,46 NTU, dan persentase penurunan $84,20 \%$. Adapun rata-rata persentase penurunan yakni sebesar $82,8 \%$.

\section{Tabel 3}

Hasil Pemeriksaan Kekeruhan Sebelum dan Sesudah Perlakuan Dengan Dosis $25 \mathrm{ml}$

\begin{tabular}{ccccc}
\hline No. & $\begin{array}{c}\text { Percobaa } \\
\mathbf{n}\end{array}$ & \multicolumn{2}{c}{$\begin{array}{c}\text { Kadar Kekeruhan } \\
\text { (NTU) }\end{array}$} & $\begin{array}{c}\text { Persentase } \\
\text { Penurunan }\end{array}$ \\
\hline & & Sebelum & Sesudah & $(\%)$ \\
1. & I & 59,9 & 10,57 & 82,35 \\
2. & II & 59,9 & 9,87 & 83,52 \\
3. & III & 59,9 & 8,46 & 85,87 \\
& Rata- Rata & $\mathbf{5 9 , 9}$ & $\mathbf{9 , 6 3}$ & $\mathbf{8 3 , 9 1}$ \\
\hline
\end{tabular}

Berdasarkan tabel 3 diketahui bahwa kadar kekeruhan sebelum pengolahan sebesar 59,9 NTU, dan kontrol sebesar 15,98 NTU. Setelah diberi perlakuan dengan menggunakan rebusan tanaman kaktus sebanyak $25 \mathrm{ml}$, pada percobaan pertama diperoleh hasil 10,57 NTU, dengan persentase penurunan $82,35 \%$. Pada percobaan kedua diperoleh hasil 9,87 NTU, dengan persentase penurunan 83,52 \%. Sedangkan pada percobaan ketiga diperoleh 8,46 NTU, dan persentase penurunan $85,87 \%$. Adapun persentase rata-rata penurunan yakni sebesar $83,91 \%$.

Berdasarkan hasil pemeriksaan kekeruhan pada air sungai setelah perlakuan, dapat dilihat persentase rata-rata penurunan, dimana pada dosis $15 \mathrm{ml}$ persentase penurunan mencapai $78,82 \%$, dosis $20 \mathrm{ml}$ persentase penurunan mencapai $82,80 \%$, dan untuk dosis $25 \mathrm{ml}$ persentase penurunannya mencapai $83,91 \%$. Untuk lebih jelasnya dapat dilihat pada gambar 1 berikut ini :

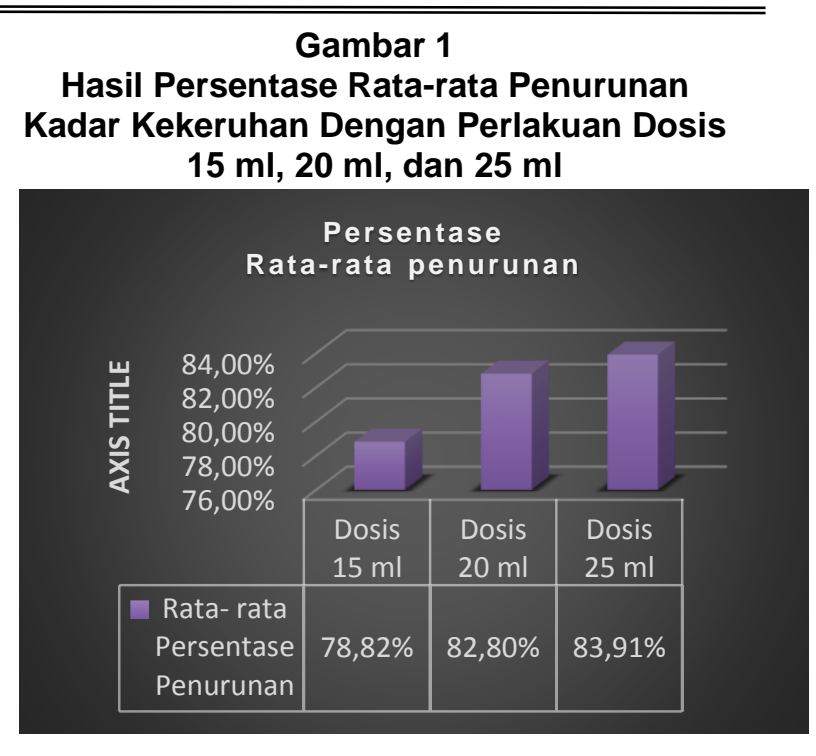

\section{PEMBAHASAN}

Kekeruhan adalah ukuran yang menggunakan ukuran efek cahaya sebagai dasar untuk mengukur keadaan air baku dengan skala NTU (Nefelometrik Turbidity Unit) atau JTU (Jakson Turbidity Unit) atau FTU (Formazi Turbidity Unit), kekeruhan ini disebabkan oleh adanya benda tercampur atau benda koloid di dalam air. Hal ini membuat perbedaan nyata dari segi estetika maupun dari segi kualitas air itu sendiri. Partikel-partikel koloid umumnya berasal dari kwarsa (pasir, tanah liat, sisa makanan, ganggang zat organik.

Air dikatakan keruh, apabila air tersebut mengandung begitu banyak partikel bahan yang tersuspensi sehingga memberikan warna/ rupa yang berlumpur dan kotor. Bahanbahan yang menyebabkan kekeruhan ini meliputi: tanal liat, lumpur, bahan- bahan organik yang tersebar secara baik dan partikel- partikel kecil yang tersuspensi lainnya.

Nilai numerik yang menunjukkan kekeruhan di dasarkan pada turut- campurnya bahan- bahan tersuspensi pada jalannya, sinar melalui sampel. (Sutrisno, dkk 2002).

Kadar kekeruhan berdasarkan Permenkes No. 416/MENKES/PER/IX/1990 bahwa standar kekeruhan yang diperbolehkan untuk air bersih yaitu 25 NTU. Kekeruhan yang melampaui batas dapat mengurangi estetika dan efektifitas desinfeksi air. 


\section{Penurunan Tingkat Kekeruhan Dengan Dosis $15 \mathrm{ml}$}

Penurunan kadar kekeruahan setelah perlakuan dengan menggunakan rebusan tanaman kaktus (Opuntia ficus indica) dengan dosis $15 \mathrm{ml}$ pada percobaan pertama setelah diberi perlakuan di peroleh hasil 15,28 NTU, dengan persentase penurunan yakni sebesar $74,50 \%$. Pada percobaan kedua setelah diberi perlakuan diperoleh hasil sebesar 11,48 NTU, dengan persentase penurunan yakni sebesar 80,83 \%. Sedangkan percobaan ketiga setelah diberi perlakuan hasil yang diperoleh sebesar 11,29 NTU, dengan persentase penurunan yakni sebesar $81,15 \%$. Adapun persentase rata-rata penurunan yakni sebesar $78,82 \%$.

Jika dilihat pada tabel 5.1, maka terlihat penurunan kadar kekeruhan pada setiap percobaan. Pada percobaan I, penurunan yang terjadi lebih rendah dari percobaan II dan III. Hal ini di sebabkan karena pada percobaan I reaksi yang terjadi belum sempurna dimana asam Dgalakturonat merupakan gugus karbosil yang saling berikatan dengan ion $\mathrm{Mg}^{2}+$ atau $\mathrm{Ca}^{2}+$. Asam D-galakturonat mengandung muatan negative, sehingga dapat mengikat segala muatan positif pada air sehingga air dapat jernih kembali.

Apabila Semakin tinggi dosis yang digunakan semakin bermanfaat dalam menurunkan kadar kekeruhan karena dosis yang tinggi mengandung kandungan zat pektin yang lebih banyak. Dosis ini merupakan dosis yang paling rendah dalam penelitian ini dimana dosis tersebut mampu menurunkan kadar kekeruhan yang terdapat dalam air sungai tersebut dengan persentase rata-rata penurunan $78,82 \%$.

\section{Penurunan Tingkat Kekeruhan Dengan Dosis $20 \mathrm{ml}$}

Berdasarkan hasil penelitian Setelah diberi perlakuan dengan menggunakan rebusan tanaman kaktus (Opuntia ficus indica) sebanyak $20 \mathrm{ml}$, pada percobaan pertama diperoleh hasil 11,29 NTU, dengan persentase penurunan yakni sebesar 81,15 $\%$. Pada percobaan kedua setelah diberi perlakuan diperoleh hasil sebesar 10,15 NTU, dengan persentase penurunan yakni sebesar $83,05 \%$. Sedangkan pada percobaan ketiga setelah diberi perlakuan hasil yang diperoleh yakni sebesar 9,46 NTU, dan persentase penurunan $84,20 \%$ Adapun rata-rata persentase penurunan yakni sebesar $82,8 \%$. Jika dibandingkan dengan dosis sebelumnya, penurunan pada dosis ini lebih tinggi pada dosis sebelumnya dengan persentase rata- rata penurunan $82,8 \%$.

Penurunan yang terjadi dikarenakan kandungan yang terdapat pada tanaman kaktus yang berfugsi dalam menurunkan kadar kekeruhan pada air. Kandungan Zat Pektin yang terdapat pada tanaman kaktus terdiri dari getah (mucilage) $\mathrm{O}$. ficus-indica mengandung asam galakturonat, rhamnosa, ksilosa , arabinosa dan galaktosa. Asam galakturonat berperan sebagai zat pengkoagulan dan meknisme koagulasinya adalah adsorpsi dan penggabungan dimana partikel tidak bersentuhan satu sama lain tetapi terikat pada senyawa seperti polimer dari kaktus.

\section{Penurunan Tingkat Kekeruhan Dengan Dosis $25 \mathrm{ml}$}

Hasil yang diperoleh setelah diberi perlakuan dengan menggunakan rebusan tanaman kaktus (Opuntia ficus indica) sebanyak $25 \mathrm{ml}$, pada percobaan pertama diperoleh hasil 10,57 NTU, dengan persentase penurunan yakni sebesar 82,35 $\%$. Pada percobaan kedua setelah diberi perlakuan diperoleh hasil sebesar 9,87 NTU, dengan persentase penurunan yakni sebesar $83,52 \%$. Sedangkan pada percobaan ketiga setelah diberi perlakuan hasil yang diperoleh yakni sebesar 8,46 NTU, dan persentase penurunan $85,87 \%$. Adapun persentase ratarata penurunan yakni sebesar $83,91 \%$.

Proses koagulasi dipengaruhi oleh kondisi dari air itu sendiri diantaranya $\mathrm{pH}$, namun dilihat dari kualitas air sampel yaitu menunjukkan $\mathrm{pH}$ yang masih optimum berkisar 7,3.

Adapun perbedaan dari penggunaan dosis sebelumnya, pada Perlakuan dengan dosis $25 \mathrm{ml}$ lebih tinggi, dengan persentase rata-rata penurunan sebesar $83,91 \%$. Hal ini disebabkan karena semakin tinggi dosis yang digunakan maka semakin tinggi pula penurunan yang terjadi, dimana kandungan zat yang terdapat pada tanaman kaktus semakin banyak. 
Jurnal Sulolipu : Media Komunikasi Sivitas Akademika dan Masyarakat

Vol. 17 No.II 2017

e-issn : 2622-6960, p-issn : 0854-624X

\section{Studi Penurunan Kadar Kekeruhan}

Dari uraian di atas, perlakuan yang telah dilakukan, yang paling besar mengalami tingkat penurunan yang terjadi setelah diberi perlakuan dengan menggunakan larutan kaktus dengan melakukan 3 kali percobaan adalah penggunaan dosis $25 \mathrm{ml}$, yang menunjukkan persentase rata- ata penurunan sebesar $83,91 \%$. Maka dari itu penggunaan tanama kaktus Opuntia ficus-indica sebagai koagulan ini dikatakan dapat bermanfaat dalam menurunkan kekeruhan pada air sungai, sesuai dengan persyaratan Permenkes No. 416/MENKES/PER/IX/1990 tentang syarat kualitas air bersih dalam hal kekeruhan yaitu sebanyak 25 NTU. Penurunan tersebut disebabkan karena kandungan zat pektin yang terdapat pada tanaman kaktus.

Zat pektin merupakan senyawa polisakarida yang bisa larut dalam air dan membentuk cairan kental (jelly) yang disebut dengan mucilage. Penyusun utama pektin biasanya polimer asam D-galakturonat, yang terkait dengan $\alpha 1,4$ glikosidik. Asam Dgalakturonat merupakan gugus karbosil yang saling berikatan dengan ion $\mathrm{Mg}^{2}+$ atau $\mathrm{Ca}^{2}+$.

Asam D-galakturonat mengandung muatan negative, sehingga dapat mengikat segala muatan positif pada air sehingga dapat menjernihkan air dan dapat menurunkan kadar kekeruhan pada air. (Hewwet et al 2011 dalam Vini 2013 dalam Arma 2015).

Terjadinya penurunan tingkat kekeruhan pada sampel air sungai tersebut juga dikarenakan koagulasi dan flokulasi adalah proses fisika dan kimia, atau suatu proses pemisahan partikel-partikel halus penyebab kekeruhan dari dalam air. Proses pemisahan di lakukan dengan cara pembubuhan bahan koagulan ke dalam air yang mengakibatkan partikel-partikel halus menggumpal menjadi partikel-partikel yang lebih besar sehingga mudah dipisahkan dari air dengan cara di endapkan, dimana diperlukan energi dan waktu agar proses dapat berlangsung. Flokulasi merupakan kelanjutan dari proses koagulasi, dimana flokflok yang sangat halus (mikroflok) hasil dari koagulasi mulai mengumpulkan partikel menjadi flok-flok yang besar (makroflok) dan dapat diendapkan. Flokulasi memberikan kesempatan kepada partikel untuk saling bertumbukan dan bergabung, cara ini dapat dilakukan dengan cara pengadukan.

Hasil penelitian ini sama halnya dengan penelitian sebelumnya yang telah dilakukan oleh Shilpa et al. (2012), menunjukkan bahwa kaktus Opuntia ficusindica mengurangi kekeruhan air danau dari 83 NTU menjadi 9,1 NTU. Getah (mucilage) dari $O$. ficus-indica mengandung asam galakturonat, rhamnosa, ksilosa, arabinosa dan galaktosa. Pada penelitian menunjukkan bahwa asam galakturonat berperan sebagai zat koagulan dan mekanisme koagulasinya adalah adsorpsi dan penggabungan dimana partikel tidak bersentuhan satu sama lain tetapi terikat pada senyawa seperti polimer dari kaktus. Dimana asam galakturonat juga adalah penyusun utama zat pektin. Oleh karena itu peneliti menggunakan tanaman kaktus sebagai koagulan dalam menurunkan kekeruhan pada air sungai.

Maka dari itu penggunaan dosis 15 $\mathrm{ml}, 20 \mathrm{ml}$, dan $25 \mathrm{ml}$ larutan kaktus dalam penelitian ini dengan melakukan 3 kali percobaan yang dilakukan di Laboratorium Jurusan Kesehatan Lingkungan Poltekkes Makassar dengan Jar Test maka di dapatkan hasil seperti pada tabel dan diagram hasil. Sehingga dapat dikatakan bahwa pada setiap penggunaan konsentrasi dosis yang berbeda, memberikan hasil penurunan kekeruhan yang berbeda pula dan penggunaan dosis tersebut bermanfaat dalam menurunkan kadar kekeruhan pada sampel air dan persentase penurunan yang paling besar terjadi pada penggunaan dosis $25 \mathrm{ml}$. Semakin tinggi dosis yang digunakan semakin bermanfaat dalam menurunkan kadar kekeruhan karena dosis yang tinggi mengandung kandungan zat pektin yang lebih banyak.

Terjadinya kekeruhan pada sampel air sungai tersebut dikarenakan terdapat saluran - saluran pembuangan air limbah rumah tangga masyarakat yang berada di lingkungan sekitar sungai tersebut, yang langsung dibuang ke sekitar aliran sungai tanpa melalui proses pengolahan terlebih dahulu, tidak hanya itu faktor lain yang juga mempengaruhi kekeruhan tersebut dikarenakan air sungai tersebut bercampur dengan pasir, lumpur, kayu, dan kotoran lainnya.

Menurut teori Sutrisno, dkk (2002) air dikatakan keruh, apabila air tersebut 
mengandung begitu banyak partikel bahan yang tersuspensi sehingga memberikan warna/ rupa yang berlumpur dan kotor. Bahan- bahan yang menyebabkan kekeruhan ini meliputi : tanah liat, lumpur, bahan- bahan organik yang tersebar secara baik dan partikel- partikel kecil yang tersuspensi lainnya, dan mempunyai ukuran butir yang sangat halus yaitu berkisar antara 1 mikron sampai 1 milimikron ( $1 \mu \mathrm{m}$ sampai $1 \mathrm{~m} \mu$ ). Karena ukurannya sangat halus maka partikel-partikel sangat halus sulit dihilangkan atau dipisahkan dari air dengan cara penyaringan biasa atau dengan cara pengendapan.

Sehingga metode yang digunakan dalam penelitian ini yakni dengan cara koagulasi-Flokulasi, kelebihan dari metode tersebut dimana partikel- partikel yang sangat halus, sulit di endapkan secara gravitasi namun bisa di endapkan dengan metode tersebut.

Hal ini sejalan dengan penelitian yang sejenis dilakukan oleh Nur Asyifa Arma (2015) hasil penelitian menunjukkan bahwa dengan menggunakan variasi ketebalan 30 $\mathrm{cm}$ dengan waktu 1 jam, $35 \mathrm{~cm}$ dengan waktu 6 jam, dan $40 \mathrm{~cm}$ dengan waktu 12 jam. Kadar kekeruhan awal yaitu 215 NTU dan setelah pengolahan hasil untuk waktu kontak 1 jam yaitu 176 NTU untuk $30 \mathrm{~cm}$. Waktu kontak 6 jam diperoleh hasil yaitu 65.95 NTU untuk $35 \mathrm{~cm}$. Waktu kontak 12 jam diperoleh hasil yaitu 33.55 NTU untuk $30 \mathrm{~cm}, 20.56$ NTU untuk $35 \mathrm{~cm}, 12.95$ NTU untuk $40 \mathrm{~cm}$. Terjadinya penurunan tersebut disebabkan karena zat pektin yang terkandung dalam kulit pisang kepok merupakan senyawa polisakarida bisa larut dalam air.
Menurut teori Sanropie dkk (1984) penyimpangan terhadap standar kualitas dalam hal kekeruhan melebihi batas yang telah ditetapkan akan menggangu estetika dan mengurangi efektifitas desinfeksi air. Maka dari itu perlunya dilakukan pengolahan salah satunya dengan cara pembubuhan koagulan dalam air untuk menurunkan kekeruhan.

\section{PENUTUP}

1. Kesimpulan

a. Tingkat kekeruhan pada air sungai sebelum dilakukan pengolahan sebesar 59,9 NTU.

b. Pembubuhan menggunakan rebusan tanaman kaktus dengan dosis $15 \mathrm{ml} / 500$ $\mathrm{ml}$ sampel air, maka diperoleh hasil dengan penurunan $78,82 \%$.

c. Pembubuhan menggunakan rebusan tanaman kaktus dengan dosis $20 \mathrm{ml} / 500$ $\mathrm{ml}$ sampel air, maka diperoleh hasil dengan penurunan $82,8 \%$.

d. Pembubuhan menggunakan rebusan tanaman kaktus dengan dosis $25 \mathrm{ml} / 500$ $\mathrm{ml}$ sampel air, maka diperoleh hasil dengan penurunan $83,91 \%$.

\section{Saran}

a. Penggunaan media tanaman kaktus dapat digunakan sebagai alternatif untuk menurunkan kadar kekeruhan pada air sungai yang melebihi standar.

b. Untuk peneliti selanjutnya sebaiknya melakukan Uji Toksisitas terlebih dahulu pada air yang sudah dilakukan pengolahan dengan tanaman kaktus.

\section{DAFTAR PUSTAKA}

Agnazgeograph. $2014 . \quad$ faktor-kekeruhan-turbiditas-air-sungai. (online). https://agnazgeograph.wordpress.com/2014/09/11/faktor-kekeruhan-turbiditas-air-sungai/. $\quad$ (Di akses pada tanggal 18 Januari 2017).

Alaerts dan Santika S S, dkk. 1984. Metode Penelitian Air. Surabaya. Usaha Nasional.

Alamsyah Sujana. 2006. Merakit Sendiri Alat Penjernih Air Untuk Rumah Tangga. Jakarta: PT.Kawan Pustaka. 
Jurnal Sulolipu : Media Komunikasi Sivitas Akademika dan Masyarakat

Vol. 17 No.II 2017

e-issn : 2622-6960, p-issn : 0854-624X

Arma Asyifah Nur. 2015. Kemampuan Kulit Pisang Kepok (Musa Acuminate L) Dalam Menurunkan Kekeruhan Pada Air Sumur Bor. Makassar: Jurusan Kesehatan Lingkungan Politeknik Kesehatan Makassar. (KTI Tidak Diterbitkan).

Asmadi, dkk. 2011. Teknologi Pengolahan Air Minum. Yogyakarta: Gosyen Publishing.

Budiyono, Sumardiono Siswo., 2013. Tehnik Pengolahan Air: Yogyakarta: Graha IImu.

Kusumarta Feldi, 2015. Efektifitas Batu Bata Sebagai Media Filter Terhadap Penurunan Kadar Kekeruhan Air Sungai Menjadi Air Bersih. Makassar: Jurusan Kesehatan Lingkungan Politeknik Kesehatan Makassar. (KTI Tidak Diterbitkan).

Lukman Rahma Siti. 2013. Uji Daya Hambat Ekstrak Buah Kaktus Pir Berduri (Opuntia Ficus Indica) Terhadap Pertumbuhan Staphylococcus Aerus Secara In Vitro. Skripsi. Universitas Hasanuddin Makassar. (Online).http://repository.unhas.ac.id/handle/123456789/1283. (Diakses Pada Tanggal 17 Januari 2017).

Rahayu Imam. 2007. Cara Menangani Air Kotor Menjadi Air Bersih. Bandung: CV. Citra Praya.

Rukmana Rahmat, dkk. 1998. Kaktus. Yogyakarta: Kanisius.

Sanropie Djasio, dkk. 1984. Pedoman Bidang Studi Penyediaan Air Bersih Akademi Penilik Kesehatan Teknologi Sanitasi (APK-TS). Jakarta: Proyek Pengembangan Pendidikan Tenaga Sanitasi Pusat Pendidikan Dan Latihan Pegawai Departemen Kesehatan R.I.

Shilpa et al. (2012). kaktus-sebagai-penjernih-air-ramah-lingkungan. (online).Https://bisakimia.com/2014/12/21/kaktus-sebagai-penjernih-air-ramah-lingkungan/. (Diakses Pada Tanggal 18 Januari 2017).

Sujadi Firman. 2008. Air Bersih Sumber Kehidupan Sehat. Bandung: Shakti Adiluhung.

Sutrisno Totok, dkk. 2002. Teknologi Penyediaan Air Bersih. Jakarta: PT. Rineka Cipta.

Syafniwati. 2011. Tanaman-kaktus. (online) .http://syafniwati-bio.blogspot.co.id/2011/07/tanamankaktus.html. (Diakses Pada Tanggal 20 Juli 2017).

Waris Abdul, 2008. Studi Penggunaan Bahan Koagulan Untuk Menurunkan Tingkat Kekeruhan Air Baku PDAM Gowa, Kabupaten Gowa 